\title{
LITERASI SEKOLAH: TANTANGAN DAN STRATEGI PELAKSANAAN
}

\author{
Yustinus Budi Setyanta \\ SMA Negeri 11 Surabaya, Jawa Timur \\ Email: yusbuset11@gmail.com
}

\begin{abstract}
Abstrak
Tulisan yang dilatarbelakangi kondisi sekolah yang belum menjadi lingkungan fisik, sosial, dan belajar yang literat ini bertujuan memberikan gambaran konkret tantangan dan strategi pelaksanaannya agar literasi membudaya di sekolah. Untuk itu, perlu dilakukan pengamatan dan pendokumentasian terhadap implementasi literasi di sekolah sehingga dapat ditentukan langkahlangkah konkret pelaksanaannya. Ada tiga tahap kegiatan untuk mewujudkannya. Pertama, pembentukan tim literasi. Kedua, pelaksanaan program berupa kegiatan-kegiatan yang berkaitan dengan literasi. Ketiga, evaluasi pelaksanaan program yang hasilnya dijadikan bahan perbaikan. Jika ketiga tahap tersebut dilakukan dengan baik, diharapkan gerakan literasi bertumbuh dan menjadikan sekolah yang literat.
\end{abstract}

Kata kunci: budaya literasi, tantangan, strategi

\begin{abstract}
The writing which is based on the condition of the school that has not become a physical, social and learning environment that is literate aims to provide a concrete picture of the challenges and implementation strategies so that literacy is entrenched in schools. For this reason, it is necessary to observe and document literacy implementation in schools so that concrete steps can be determined. There are three stages of activities to make it happen, namely the formation of a literacy team, the implementation of the program in the form of activities related to literacy, and the evaluation of the implementation of the program whose results are made as improvement material. If all three stages are carried out well, it is hoped that the literacy movement will grow and become a literate school.
\end{abstract}

Keywords: literacy culture, literate schooling, challenges, strategies 


\section{PENDAHULUAN}

Kenyataan menunjukkan bahwa Indonesia berada di posisi kedua dari bawah tentang kegiatan berliterasi. Hasil survei Central of Connecticut State University (OCSU) pada 2016 menempatkan Indonesia pada posisi 60 dari 61 negara yang disurvei (Dewayani, 2017:2). Mengamini survei tersebut, UNESCO merilis data minat baca masyarakat Indonesia yang hanya sebesar 0,001\%. Artinya, dari 1.000 orang hanya ada 1 orang yang memiliki hobi membaca (www.kominfo. co.id).

Berdasarkan kondisi tersebut, pemerintah sejak 2015, sebenarnya telah mencanangkan Gerakan Literasi Sekolah (GLS). Akan tetapi, dalam praktiknya pelaksanaannya tidaklah mudah. Berdasarkan pengamatan, kegiatan berliterasi di tingkat sekolah, mulai jenjang pendidikan dasar hingga menengah memang telah dilaksanakan, namun tampaknya hanya sekadar untuk menggugurkan kewajiban.

Kepedulian sekolah dalam menyukseskan GLS sesungguhnya sangatlah penting. Akan tetapi, jujur harus kita akui bahwa kegiatan dasar literasi, baik membaca maupun menulis belum menjadi suatu tradisi positif di sekolah. Hal itu adalah suatu kontradiksi karena sekolah merupakan institusi belajar yang mau atau tidak mau berkaitan dengan literasi. Minat baca dan tulis di kalangan peserta didik, bahkan guru, pada kenyataannya masih sangat rendah. Untuk itu, kepala sekolah memiliki peran pokok yang tidak hanya berkaitan dengan peningkatan kualitas pembelajaran, tetapi juga kualitas pendidikan. Oleh sebab itu, diperlukan suatu pembaruan agar minat baca dan tulis meningkat.

Kini sudah tiba saatnya bagi sekolah untuk berbenah secara serius dengan melakukan pembiasaan berliterasi. Hal tersebut bertujuan untuk menumbuhkan kesadaran bagi semua warga sekolah, baik peserta didik, guru, maupun kepala sekolah bahwa pengetahuan dan wawasan keilmuan akan berkembang dengan baik jika mereka memiliki kebiasaan membaca.

Akan tetapi, yang perlu diperhatikan sehubungan dengan kegiatan membaca adalah program membaca bebas sebelum pembelajaran, seperti yang dicanangkan dalam Permendikbud Nomor 23 Tahun 2015, tidak hanya sekadar meluangkan waktu khusus, tetapi lebih kepada penyamaan persepsi dan pemahaman tentang yang baik tentang prinsip-prinsip membaca bebas (Laksono, 2016:1).

Sementara itu, aspek kreativitas akan semakin meningkat melalui kegiatan menulis. Dampak dari kegiatan tersebut adalah adanya peningkatan kesadaran segenap warga sekolah bahwa kegiatan, baik membaca maupun menulis perlu ditumbuhkembangkan sejak dini sehingga hal itu akan menjadi budaya.

Berdasarkan latar belakang masalah tersebut, tulisan ini bertujuan agar sekolah mampu memahami tantangan dan strategi pelaksanaan GLS secara tepat sehingga mampu menjadikan dirinya sebagai sekolah yang literat.

Untuk itu, ruang lingkup masalah dalam tulisan ini meliputi enam hal, yakni konsep dasar literasi, kondisi literasi di Indonesia, kebijakan pemerintah tentang literasi, budaya literasi sekolah, tantangan pelaksanaan budaya literasi sekolah, dan strategi pelaksanaan budaya literasi sekolah. Hal-hal tersebut dipaparkan secara singkat pada bagian berikut. 


\section{KONSEP DASAR LITERASI}

Literasi tidak hanya sekadar membaca dan menulis, melainkan juga mencakup keterampilan berpikir dengan menggunakan sumber-sumber pengetahuan, baik dalam bentuk cetak, visual, digital, maupun auditori. Pada abad XXI ini, kemampuan tersebut dikenal dengan literasi informasi.

Clay (2001) dan Ferguson (www.bibliotech.us/pdf/infolit.pdf) menjelaskan bahwa komponen literasi informasi terdiri atas enam komponen, yakni

1. Literasi Dini, yakni kemampuan memahami bahasa lisan dan gambar berdasarkan pengalaman berliterasi dengan lingkungan sosialnya.

2. Literasi Dasar, yakni kemampuan mendengarkan, berbicara, membaca, menulis, dan menghitung.

3. Literasi Perpustakaan, yaki kemampuan membedakan bacaan fiksi dan nonfiksi hingga mampu memahami informasi di dalamnya.

4. Literasi Media, yakni kemampuan mengetahui berbagai bentuk media dan tujuan penggunaannya.

5. Literasi Teknologi, yakni kemampuan memahami perangkat teknologi informasi dan etika pemanfaatannya.

6. Literasi Visual, yakni kemampuan tingkat lanjut antara literasi media dan literasi teknologi dengan memanfaatkan materi visual dan audio-visual.

\section{KONDISI LITERASI DI INDONESIA}

Prihatin. Itulah kata yang mungkin tepat dipakai jika kita berbicara tentang kondisi literasi Indonesia dewasa ini. Bagaimana tidak merasa prihatin jika pada kenyataannya aktivitas literasi dasar yang berkaitan dengan membaca dan menulis masih sangat rendah. Hal yang demikian tentu akan dilihat dan dicatat oleh negara-negara lain, terutama negara-negara tetangga. Kenyataan tersebut adalah realita pahit yang terjadi dan harus dihadapi bangsa Indonesia.

Berdasarkan beberapa kajian tentang literasi, baik yang dilakukan oleh lembaga nasional maupun internasional, baik yang dilakukan oleh institusi pemerintah maupun nonpemerintah, terindikasikan bahwa indeks minat baca dan tingkat literasi masyarakat kita masih sangat memprihatinkan. United Nations Educational, Scientific and Cultural Organization (UNESCO) dan Organization for Economic Cooperation and Development (OECD) pernah merilis data tentang hal tersebut. Data yang diunggah UNESCO menunjukkan bahwa indeks minat baca masyarakat Indonesia hanya sebesar 0,001 persen (https://kompas.id). Hal itu dapat dimaknai bahwa hanya seorang di antara seribu orang yang memiliki minat baca. Perlu diingat, laporan tersebut hanya didasarkan pada aspek "minat baca", belum diungkapkan aspek yang lain. Dengan demikian, belum tentu orang yang tergolong memiliki minat baca, berarti juga gemar membaca. Jika memang orang tersebut gemar membaca, belum tentu pula orang itu membaca tulisan-tulisann atau buku-buku yang berkualitas.

Sementara itu, OECD melakukan serangkaian tes. Dari data yang didasarkan pada hasil tes The Programme International Student Assessment (PISA) terindikasikan bahwa kemampuan berliterasi (membaca, berhitung, dan pengetahuan sains) anak-anak Indonesia masih belum bias mengalahkan negara-negara tetangga, misalnya Singapura, Malaysia, Vietnam, dan Thailand. Ironisnya, Indonesia sejajar dengan negara-negara miskin di Afrika (https://www. oecd. org/pisa/pisa). 
Indeks membaca dan tingkat literasi yang rendah tersebut, tidak hanya terjadi pada anak-anak, tetapi juga orang dewasa, Menurut kajian tersebut, indeks membaca orang dewasa juga berada pada tataran bawah. Hal itu terlihat dari hasil kajian The Programme for International Assessment of Adult Competencies, sebuah tes kompetensi secara sukarela yang ditujukan kepada orang dewasa yang. Dari empat puluh negara yang dilakukan tes, Indonesia di posisi buncit.

Berkaitan dengan beberapa hasil penelitian tersebut, World Economic Forum memaparkan bahwa tingkat literasi dasar yang harus dikuasai oleh orang dewasa terdiri atas literasi membaca dan menulis, numerasi, finansial, sains, budaya dan kewarganegaraan, serta teknologi informasi dan komunikasi (https:// www.oecd.org/).

Kenyataan yang memprihatinkan tersebut semakin diperparah sejak era teknologi komunikasi semakin merebak bagaikan jamur di musim penghujan. Saat ini buku dan komik tidak lagi menjadi magnet yang menarik keingintahuan anak-anak, tetapi telah beralih ke telepon pintar dengan berbagai aplikasi yang ada di dalamnya. Kenyataan seperti itu terlihat di sekeliling kita, baik di rumah maupun di sekolah. Anak-anak terdiam dan tertunduk karena sedang bermain game atau aktif berkomunikasi di dunia maya melalui gawai dalam genggaman tangan mereka. Sudah sangat jarang ditemui mereka duduk di suatu tempat untuk membaca buku-buku, baik buku pelajaran, buku pengetahuan umum, komik, maupun novel. Oleh sebab itu, perlu dilakukan upaya serius dengan membuat gerakan agar budaya membaca dan menulis bertumbuh dan berkembang di kalangan anak-anak.

Berdasarkan realita yang sangat memprihatinkan tersebut, Kemendikbud mengeluarkan peraturan yang tertuang dalam Permendikbud Nomor 23 Tahun 2015. Pemerintah menyadari pentingnya penumbuhan karakter peserta didik melalui kebijakan membaca selama lima belas menit sebelum pembelajaran dimulai. Namun demikian, untuk menyukseskan rencana agung tersebut, tidak dapat dilakukan secara sederhana dan bersifat tentatif karena yang akan dicetak dan dibentuk adalah faktor budaya manusia, dalam hal ini guru dan peserta didik. Oleh sebab itu, diperlukan suatu kegiatan, lebih tepatnya gerakan, yang harus terus-menerus dilakukan sejak dini agar terwujud kebiasaan membaca dan menulis dalam diri peserta didik.

\section{KEBIJAKAN PEMERINTAH TENTANG LITERASI}

Nawacita, sembilan agenda prioritas, telah ditetapkan pemerintah dan tertuang dalam Rencana Pembangunan Jangka Menengah Nasional (RPJMN) 2015-2019. Nawacita tersebut berlandaskan pada Ideologi Trisakti yang terdiri atas tiga hal: (1) berdaulat di bidang politik, (2) berdikari di bidang ekonomi, dan (3) berkepribadian dalam kebudayaan.

Berkaitan dengan hal tersebut, pembangunan pendidikan dan kebudayaan terarah pada perwujudan Nawacita, khususnya yang terdapat pada poin 5 (meningkatkan kualitas hidup manusia Indonesia), poin 6 (meningkatkan produktivitas dan daya saing), poin 8 (melakukan revolusi karakter bangsa), dan poin 9 (memperteguh kebhinekaan dan memperkuat restorasi sosial Indonesia). Demi tercapainya tujuan tersebut, upaya pengembangan dan penguatan karakter bangsa dilakukan melalui berbagai kegiatan berliterasi secara simultan, holistik, dan dilaksanakan secara bersama-sama dengan pembangunan lingkungan (ekositem) pendidikan dalam lingkup keluarga, sekolah, dan masyarakat.

Salah satu faktor penting kemajuan sebuah negara yang harus dilakukan di era global ini melalui pengembangan dan penguatan karakter, selain tentu saja kegiatan literasi. Forum Ekonomi Dunia 
pada 2015 memberikan gambaran umum tentang keterampilan abad ke-21 yang harus dikuasai yang meliputi literasi dasar, kompetensi, dan karakter. Tiga hal tersebut harus dimiliki oleh seluruh bangsa. Agar pembangunan Indonesia pada abad ke-21 berjalan dengan lancar, menjadi sebuah keharusan bagi kita untuk menguasai enam literasi dasar, seperti yang telah dikemukakan pada bagian sebelumnya. Kemampuan literasi tersebut tentu saja harus diimbangi dengan upaya untuk mengembangkan kompetensi berpikir kritis, meningkatkan keandalan memecahkan masalah, meningkatkan kreativitas, mengupayakan kemahiran berkomunikasi, dan menumbuhkan kecakapan berkolaborasi.

Untuk meningkatkan kualitas hidup, daya saing, pengembangan karakter bangsa, dan pengembangan keterampilan, serta kompetensi yang dibutuhkan di abad ke-21, Kemdikbud menyelenggarakan berbagai kegiatan literasi. Tujuannya adalah untuk meningkatkan indeks literasi nasional yang dilakukan melalui Gerakan Literasi Nasional (GLN) (http://dikdas.kemdikbud.go.id).

GLN tercipta dari penyatupaduan semua program literasi yang telah dilakukan dan sedang berlangsung pada setiap unit pokok yang ada di Kemdikbud. Dengan demikian, GLN merupakan upaya menyinergikan semua potensi dan untuk memperluas keterlibatan masyarakat dalam pengembangan budaya literasi. Oleh sebab itu, GLN harus dapat dilaksanakan secara simultan dan masif, baik di lingkup keluarga, sekolah, maupun masyarakat. Dengan demikian, Gerakan Literasi Sekolah (GLS) yang merupakan bagian GLN menjadi sesuatu yang penting adanya (Permendikbud) Nomor 23 Tahun 2015 tentang Pendidikan Budi Pekerti.

\section{BUDAYA LITERASI SEKOLAH}

Literasi harus menjadi sebuah budaya. Untuk itu, literasi di sekolah merupakan pengharapan akan terciptanya pembiasaan pada seluruh warga sekolah melalui berbagai aktivitas literasi, misalnya menyimak, berbicara, membaca, dan menulis.

Hal tersebut sejalan dengan pendapat Wiedarti (2016:7) bahwa aktivitas literasi harus bersifat partisipatif dan kolaboratif dengan pelibatan seluruh warga sekolah, baik peserta didik, guru, kepala sekolah, tenaga kependidikan, pengawas sekolah, komite sekolah, maupun orang tua/wali peserta didik. Selain itu, peran penerbit juga menjadi hal yang penting karena berkaitan dengan harga jual buku. Tidak bisa dimungkiri bahwa harga buku di Indonesia relatif mahal. Bagaimana masyarakat akan memiliki kegemaran membaca buku jika harganya mahal? Bagaimana masyarakat memiliki kreativitas menulis jika media massa tidak memberikan ruang seluas-luasnya, kesempatan terlibat, dan kemudahan mewujudkannya? Bagaimana masyarakat memiliki budaya literasi jika pemangku kepentingan tidak memiliki program konkret yang mampu memfasilitasi kegiatan literasi? Berbagai pertanyaan tersebut akan dapat terjawab jika semua komponen terkait mampu menciptakan suatu lingkungan literasi yang kondusif.

Sekali lagi, peran sekolah menjadi demikian penting adanya. Untuk itu, langkah awal yang perlu dilakukan agar kegiatan literasi menjadi sebuah budaya di sekolah adalah dengan membiasakan peserta didik membaca yang diikuti kegiatan menulis yang dilakukan secara rutin dan berkelanjutan. Jika pembiasaan membaca telah terbentuk, akan diarahkan ke tahap perkembangan pembelajaran berikutnya, kemudian dikaitkan dengan materi pembelajaran yang disesuaikan dengan tuntutan 
kompetensi dasar yang ada pada Kurikulum 2013. Untuk tujuan tersebut, kegiatan pembelajaran dapat dilakukan dengan melakukan sinkronisasi antara keterampilan reseptif dan produktif.

Budaya literasi sekolah memiliki dua tujuan: tujuan umum (berkaitan dengan membiasakan peserta didik menjadi pembelajar sepanjang hayat) dan tujuan khusus yang terdiri atas beberapa hal berikut.

1. Mengembangkan budaya berliterasi di sekolah.

2. Meningkatkan kapasitas warga dan lingkungan sekolah agar literat.

3. Menjadikan sekolah sebagai taman belajar yang menyenangkan dan ramah anak agar warga sekolah mampu mengelola dan mengelaborasi berbagai pengetahuan.

4. Menjaga keberlangsungan kegiatan pembelajaran dengan menyediakan berbagai jenis buku bacaan dan mewadahi berbagai strategi membaca.

\section{TANTANGAN PELAKSANAAN BUDAYA LITERASI SEKOLAH}

Tantangan yang dihadapi sekolah dalam kaitannya dengan budaya literasi adalah masih belum terlaksananya kegiatan literasi. Ada beberapa tantangan yang diindikasikan menjadi penyebab gerakan literasi sekolah belum terlaksana dengan baik. Tantangan tersebut berasal dari beberapa faktor, yakni faktor peserta didik, guru, dan sekolah.

Berdasarkan faktor peserta didik, tantangan itu berupa belum dimilikinya sebuah kesadaran bahwa membaca memiliki peran penting untuk menambah pengetahuan dan wawasan. Peserta didik lebih asyik dengan dunia gadge-nya. Game online dan media sosial di dunia maya adalah fokus mereka. Selain itu, mereka belum memiliki keterampilan menulis meskipun hanya berupa tulisan singkat dan sederhana.

Berdasarkan faktor guru, tantangan itu berupa sikap guru yang masih terkesan kurang acuh terhadap kegiatan literasi di sekolah. Selain itu, sangat sedikit guru yang berkunjung ke perpustakaan untuk membaca buku. Hal lainnya adalah sebagian besar guru belum menjadikan dirinya sebagai teladan bagi peserta didik berkaitan dengan budaya literasi. Minimnya karya tulis para guru adalah hal yang nyata.

Berdasarkan faktor sekolah, tantangan itu berupa program sekolah yang belum mengakomodasi budaya literasi sebagai prioritas program sekolah. Kegiatan-kegiatan yang berkaitan dengan program literasi hampir bisa dikatakan jarang dilakukan. Selain itu, adanya keterbatasan anggaran untuk mewujudkan kegiatan literasi. Hal yang demikian pasti akan berdampak pada minimnya jumlah buku bacaan di perpustakaan sekolah. Kalau pun secara kuantitas tercukupi jumlahnya, namun buku-buku yang tersedia di perpustakaan sekolah tidak menarik minat peserta didik dan guru untuk membacanya.

\section{STRATEGI PELAKSANAAN BUDAYA LITERASI SEKOLAH}

Beers, dkk. (2009) dalam A Principal's Guide to Literacy Instruction, menyatakan bahwa strategi sangat diperlukan guna terciptanya budaya literasi sekolah yang positif (www.bibliotech.us/pdfs/InfoLit.pdf). Tiga strategi tersebut adalah sebagai berikut.

1. Mengondisikan lingkungan fisik yang ramah literasi;

2. Mengupayakan lingkungan sosial sebagai model interaksi dan komunikasi yang literat;

3. Mengupayakan sekolah sebagai lingkungan belajar yang literat. 
Untuk mewujudkan lingkungan fisik yang ramah literasi, perlu diciptakan lingkungan sekolah yang nyaman dan menyenangkan bagi peserta didik untuk kegiatan berliterasi, misalnya dengan menata ruang perpustakaan yang menarik, representatif, dan nyaman dengan melengkapinya dengan sarana yang memadai. Untuk mewujudkan lingkungan sosial sebagai model komunikasi dan interaksi yang literat, perlu diciptakan suatu jalinan komunikasi yang harmonis di antara semua warga sekolah. Sementara itu, untuk mewujudkan sekolah sebagai lingkungan belajar yang literat, perlu disediakan berbagai bacaan yang bermanfaat dan menarik minat warga sekolah untuk membacanya.

Berkaca dari tiga strategi tersebut, budaya literasi di sekolah sudah saatnya dan sewajarnya menjadi program prioritas. Untuk itu, seluruh pemangku kepentingan di sekolah harus memiliki kesepakatan untuk memasukkan program literasi dalam Rencana Kegiatan dan Anggaran Sekolah (RKAS).

Berkaitan dengan hal tersebut, ada beberapa pedoman dalam melaksanakan strategi tersebut. Ketiga pedoman yang dimaksud adalah rasa ingin tahu, dimotori guru, dan banyak kompetisi literasi. Halhal tersebut dipaparkan secara singkat berikut ini.

Rasa ingin tahu. Gerakan ini mampu mewadahi keingintahuan peserta didik terhadap segala hal yang ada di sekitar mereka. Gerakan ini mampu memotivasi peserta didik untuk memiliki kebiasaan membaca sehingga akan menambah wawasan peserta didik tentang berbagai hal. Selanjutnya, setelah kebiasaan membaca itu terbentuk, akan dihasilkan pula tulisan-tulisan kreatif karya peserta didik, baik secara individu maupun kelompok.

Dimotori guru. Guru mata pelajaran Bahasa Indonesia, Bahasa Inggris, Bahasa Daerah, dan Bahasa Asing harus menjadi penggerak pelaksanaan literasi sekolah. Mereka adalah guru-guru yang memiliki pemahaman baik tentang penerapan literasi. Di bawah pembinaan dan pengawasan langsung dari guru-guru tersebut, gerakan ini akan dapat mencapai target yang telah ditentukan.

Banyak kompetisi literasi. Berbagai kompetisi tentang membaca dan menulis untuk peserta didik di tingkat SD, SMP, atau SMA cukup banyak dan bervariasi, baik yang diselenggarakan di tingkat kota, provinsi, nasional, bahkan internasional. Dengan demikian, akan tercipta peluang untuk berprestasi.

Berdasarkan ketiga pedoman tersebut, dalam strategi pelaksanaannya, ada tiga tahap kegiatan yang akan dilakukan, yakni tahap perencanaan, pelaksanaan, dan evaluasi. Ketiga tahap tersebut dipaparkan secara singkat pada bagian berikut ini.

\section{Tahap Perencanaan}

Pada tahap ini ada beberapa kegiatan yang dilakukan di sekolah.

1. Pembentukan Tim Literasi Sekolah

Kepala sekolah, berdasarkan masukan dari para staf, menyusun Tim Pengembangan Budaya Literasi Sekolah. Untuk itu, perlu dibuat Surat Keputusan dan Surat Tugas yang berkaitan dengan kegiatan tersebut, disertai dengan diskripsi tugas.

2. Pelaksanaan Koordinasi

Tim Pengembangan Budaya Literasi mengadakan koordinasi awal untuk menyusun draf perencanaan program budaya literasi. Hasil perencanaan program tersebut kemudian didiskusikan untuk proses pematangan program. 


\section{Penyusunan Program}

Tim Pelaksana Program mulai bekerja dengan menyusun program dan rencana anggaran pelaksanaan program.

4. Sosialisasi Program

Kepala sekolah memberikan sosialisasi tentang budaya literasi dan pelaksanaannya kepada seluruh tim pengembangan budaya literasi, guru, komite sekolah, dan orang tua peserta didik.

\section{Tahap Pelaksanaan}

Pada tahap pelaksanaan ini ada beberapa kegiatan yang dilakukan, yakni sebagai berikut.

1. Wajib Kunjung Perpustakaan

Kegiatan ini diimplementasikan dengan cara menyusun jadwal kunjungan ke perpustakaan sehingga setiap kelas memiliki kesempatan yang sama mengunjungi perpustakaan. Bukan hanya sekadar berkunjung, melainkan mewajibkan peserta didik meminjam buku, menyusun ringkasan atas buku yang telah dibacanya, kemudian peserta didik mengembalikan buku tersebut dalam kurun waktu yang telah ditentukan.

2. Membaca Buku Nonpelajaran

Kegiatan ini dilaksanakan sekali seminggu pada hari tertentu selama lebih kurang lima belas menit sebelum pembelajaran jam pertama dimulai.

3. Majalah Dinding

Pembuatan mading di setiap kelas dilakukan dengan cara mewajibkan peserta didik untuk berkeliling di lingkungan sekitar sekolah selama lima belas menit saat pembelajaran sedang berlangsung. Setelah itu, peserta didik diminta untuk membuat suatu tulisan pendek atas apa yang dilihat atau diamatinya. Hasil tulisan tersebut ditempelkan pada mading kelas. Program ini dilakukan setiap seminggu sekali pada hari tertentu.

4. Pohon Literasi Kelas

Pohon literasi dibuat oleh peserta didik secara mandiri dengan bimbingan guru atau wali kelas. Daun-daun yang ada pada pohon literasi yang terbuat dari kertas ditulisi dengan cita-cita, karakter mulia, paragraf pendek tentang harapan peserta didik, atau cerita pengalaman singkat.

5. Posterisasi Sekolah

Membuat poster-poster yang berisi ajakan, motivasi, dan kata-kata mutiara yang berkaitan dengan budaya literasi. Poster-poster tersebut kemudian ditempel atau digantung di beberapa sudut di kelas atau di sekolah yang mudah dilihat dan dibaca, baik oleh peserta didik maupun guru. Untuk itu, keterlibatan peserta didik dan guru dalam membuat kalimat ajakan atau motivasi sangat diperlukan.

6. Dinding Motivasi

Dinding motivasi adalah sebuah hiasan dinding kelas yang berisi kata-kata motivasi yang dibuat oleh peserta didik sendiri sebagai suatu inspirasi. Untuk itu, peserta didik dapat mencarinya di internet, namun akan lebih baik jika peserta didik berkreasi sendiri. Kata-kata tersebut dibuat secara berkelompok. 


\section{Sudut-Sudut Baca}

Sudut-sudut baca di sekolah sangat diperlukan peserta didik untuk mengisi waktu luang di selasela istirahat. Hal itu perlu dilakukan karena ruang perpustakaan yang relatif sempit sehingga tidak akan menampung jumlah peserta didik yang relatif banyak.

8. Lomba Karya Literasi

Lomba Karya Literasi antarkelas menjadi salah satu program gerakan literasi sekolah yang menarik. Lomba tersebut dapat berupa lomba mading antarkelas, lomba menulis puisi, lomba membaca cerpen, lomba debat, lomba poster antarkelas, lomba membuat pohon literasi, dll.

\section{Tahap Evaluasi}

Evaluasi dilaksanakan dalam forum diskusi dewan guru berdasarkan catatan, dokumentasi, dan kendala-kendala yang dihadapi selama program berlangsung. Hasil evaluasi digunakan sebagai bahan untuk menentukan rencana tindak lanjut. Oleh sebab itu, kegiatan pada tahap evaluasi ini meliputi dua hal berikut.

1. Monitoring

Kepala sekolah bersama tim inti melakukan monitoring pelaksanaan program budaya literasi sekolah.

\section{Koordinasi Rutin}

Mengadakan koordinasi rutin sebulan sekali yang dihadiri oleh seluruh anggota tim pelaksana program budaya literasi sekolah.

Untuk melaksanakan strategi tersebut, ada beberapa instrumen yang diperlukan. Pengumpulan data dalam pelaksanaan program ini dilakukan dengan teknik dokumentasi. Dokumentasi dilakukan untuk mengetahui beberapa hal berikut, yakni (1) kunjungan peserta didik ke perpustakaan, (2) daftar buku dan hasil resume, dan (3) hasil tulisan peserta didik.

Aktivitas peserta didik yang berkunjung ke perpustakaan untuk membaca buku, baik fiksi maupun nonfiksi pada saat jam istirahat sekolah didata. Data-data tersebut diambil dari petugas perpustakaan sekolah. Setiap satu bulan sekali, yakni pada akhir bulan dilakukan rekapitulasi dengan menggunakan format berikut.

Tabel 1. Jumlah Kunjungan ke Perpustakaan

\begin{tabular}{|c|c|c|c|c|c|c|c|c|}
\hline \multirow{3}{*}{ No } & \multirow{3}{*}{ Bulan } & \multicolumn{6}{|c|}{ Jumlah Peminjam } & \multirow{3}{*}{ Jumlah } \\
\hline & & \multicolumn{2}{|c|}{ Kelas ... } & \multicolumn{2}{|c|}{ Kelas ... } & \multicolumn{2}{|c|}{ Kelas ... } & \\
\hline & & $\mathrm{F}$ & NF & $\mathrm{F}$ & NF & $\mathrm{F}$ & NF & \\
\hline 1 & Agustus & & & & & & & \\
\hline 2 & September & & & & & & & \\
\hline 3 & Oktober & & & & & & & \\
\hline 4 & November & & & & & & & \\
\hline 5 & Desember & & & & & & & \\
\hline 6 & Januari & & & & & & & \\
\hline
\end{tabular}




\begin{tabular}{|c|c|c|c|c|c|c|c|c|}
\hline \multirow{3}{*}{ No } & \multirow{3}{*}{ Bulan } & \multicolumn{6}{|c|}{ Jumlah Peminjam } & \multirow{3}{*}{ Jumlah } \\
\hline & & \multicolumn{2}{|c|}{ Kelas ... } & \multicolumn{2}{|c|}{ Kelas ... } & \multicolumn{2}{|c|}{ Kelas ... } & \\
\hline & & $\mathrm{F}$ & $\mathrm{NF}$ & $\mathrm{F}$ & $\mathrm{NF}$ & $\mathrm{F}$ & $\mathrm{NF}$ & \\
\hline 7 & Februari & & & & & & & \\
\hline 8 & Maret & & & & & & & \\
\hline 9 & April & & & & & & & \\
\hline 10 & Mei & & & & & & & \\
\hline
\end{tabular}

Keterangan:

$\mathrm{F} \quad=$ Buku Fiksi

$\mathrm{NF}=$ Buku Nonfiksi

Sementara itu, untuk mengetahui aktivitas membaca peserta didik digunakan instrumen yang berupa "Buku Literasi". Dalam buku tersebut disiapkan kolom-kolom untuk diisi oleh peserta didik dan diketahui guru yang mengajar pada saat itu. Kegiatan ini dilaksanakan pada hari tertentu pada setiap minggunya. Kegiatan tersebut dilaksanakan selama lima belas menit sebelum pembelajaran.

Kegiatan yang dilakukan pada tahap ini adalah sebagai berikut.

1. Peserta didik membaca buku (fiksi/nonfiksi) selama lebih kurang lima belas menit.

2. Peserta didik menuliskan judul buku dan nomor halaman yang dibaca, serta membuat resume atas hasil bacaan pada hari itu.

3. Guru memberikan paraf pada "Buku Literasi" untuk masing-masing peserta didik di kelas tersebut.

Untuk itu, pada "Buku Literasi" dibuat dengan format berikut.

Tabel 2 Format Rekapitulasi "Buku Literasi”

\begin{tabular}{|c|c|c|c|c|c|c|c|}
\hline \multirow{2}{*}{ No } & \multirow{2}{*}{$\operatorname{Tgl}$} & \multirow{2}{*}{$\begin{array}{l}\text { Judul } \\
\text { Buku }\end{array}$} & \multicolumn{2}{|c|}{ Jenis Buku } & \multirow{2}{*}{$\begin{array}{c}\text { Halaman } \\
\text { yang Dibaca }\end{array}$} & \multirow{2}{*}{ Resume } & \multirow{2}{*}{$\begin{array}{l}\text { Paraf } \\
\text { Guru }\end{array}$} \\
\hline & & & $\mathbf{F}$ & NF & & & \\
\hline \multicolumn{8}{|l|}{1} \\
\hline \multicolumn{8}{|l|}{2} \\
\hline \multicolumn{8}{|l|}{3} \\
\hline \multicolumn{8}{|l|}{$\ldots$} \\
\hline $\mathrm{N}$ & & & & & & & \\
\hline
\end{tabular}

Dokumentasi berikutnya berupa hasil karya tulis peserta didik, baik yang dipajang di majalah sekolah, majalah dinding sekolah, majalah dinding kelas, maupun yang dibuat dalam bentuk buku. Untuk menjaring data tersebut, digunakan format berikut. 
Tabel 3. Format Rekapitulasi Hasil Karya Tulis Peserta didik

\begin{tabular}{|c|c|c|c|c|c|c|c|}
\hline \multirow[b]{2}{*}{ No } & \multirow[b]{2}{*}{ Nama Siswa } & \multirow[b]{2}{*}{ Kelas } & \multicolumn{2}{|c|}{ Jenis } & \multicolumn{3}{|c|}{ Media Pemuatan } \\
\hline & & & $\mathrm{F}$ & $\mathrm{NF}$ & $\begin{array}{l}\text { Mading } \\
\text { Sekolah }\end{array}$ & $\begin{array}{c}\text { Mading } \\
\text { Kelas }\end{array}$ & $\begin{array}{c}\text { Media } \\
\text { Lain }\end{array}$ \\
\hline 1 & & & & & & & \\
\hline 2 & & & & & & & \\
\hline$\ldots$ & & & & & & & \\
\hline $\mathrm{N}$ & & & & & & & \\
\hline
\end{tabular}

Beberapa dokumentasi kegiatan literasi tampak seperti foto-foto berikut.

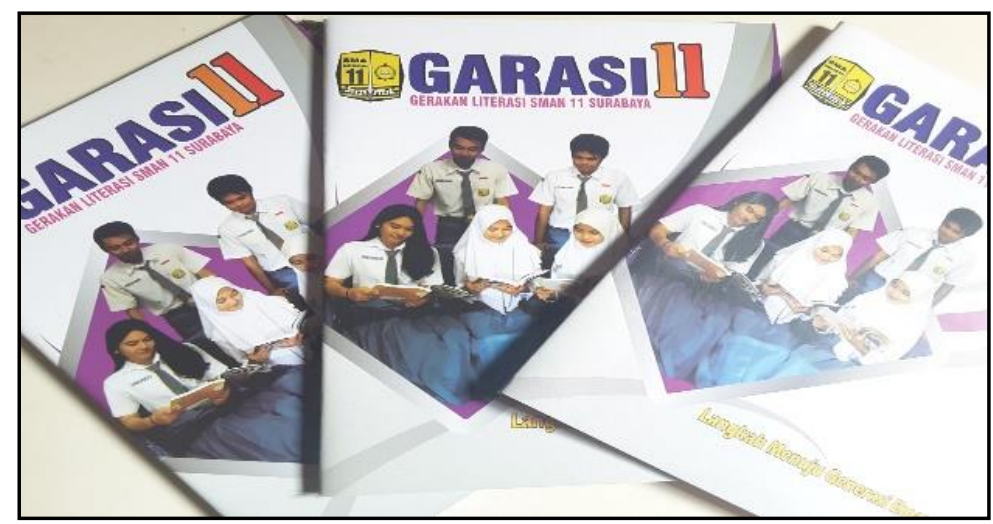

Foto 1. Buku Literasi Peserta Didik "Garasi 11"

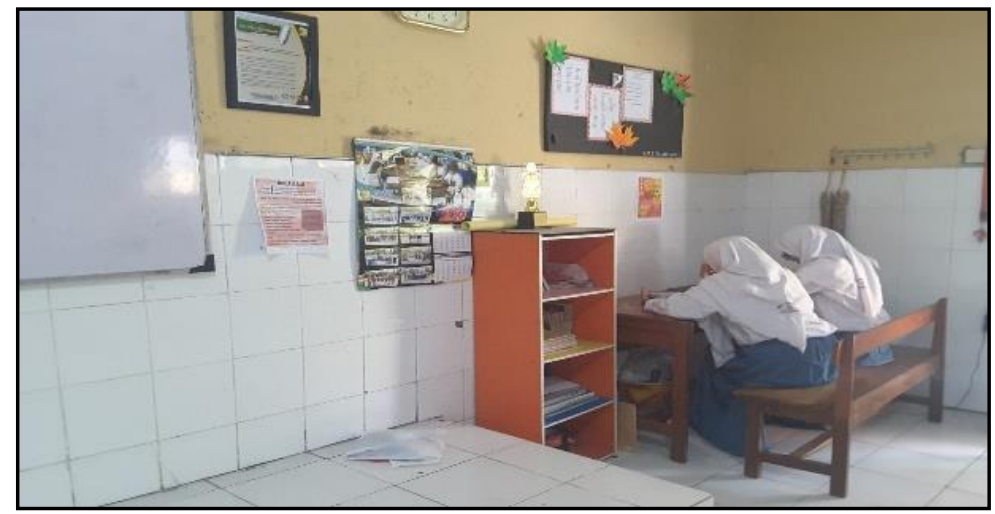

Foto 2. Sudut Baca yang ada di setiap kelas 

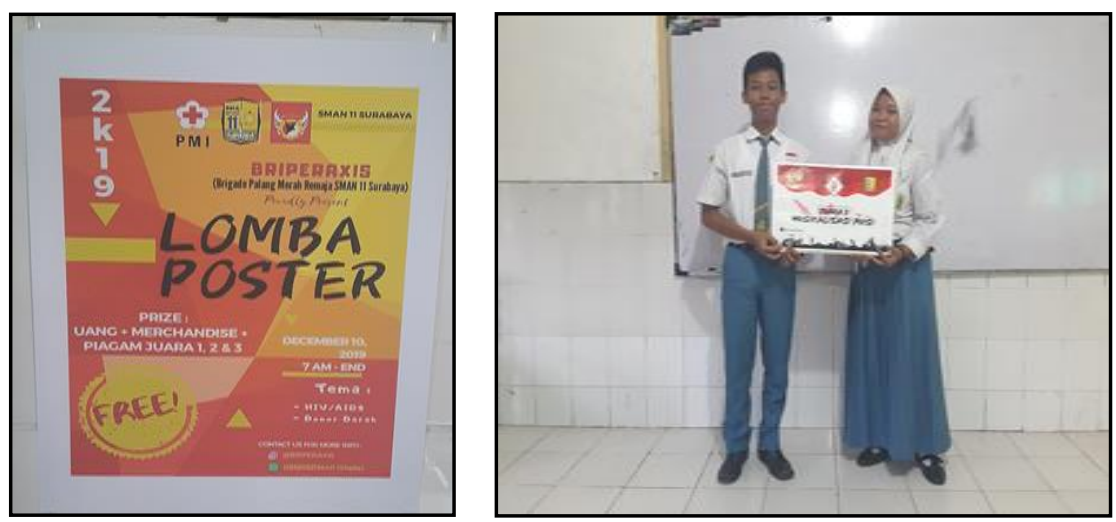

Foto 3. Lomba Literasi Antar Kelas
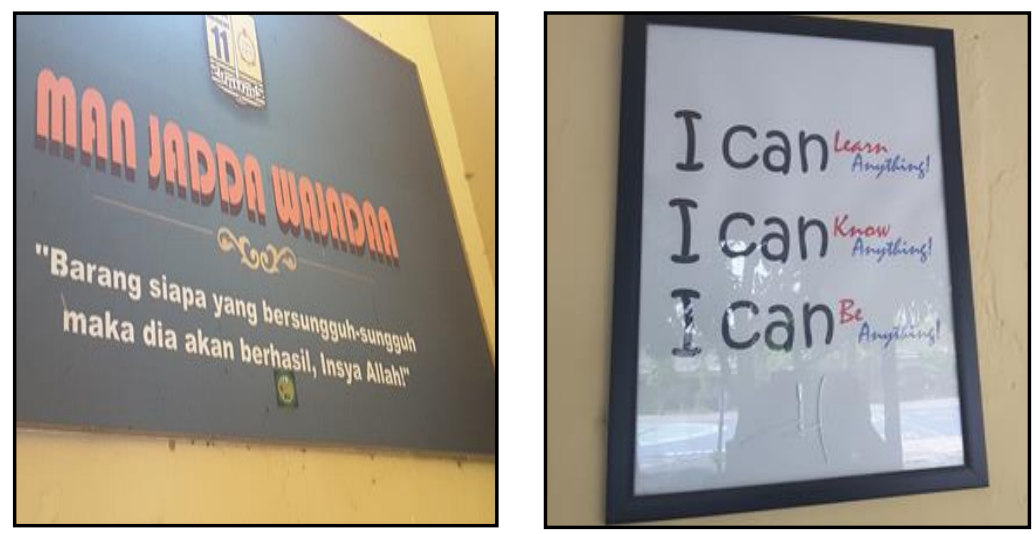

Foto 4. Dinding Motivasi
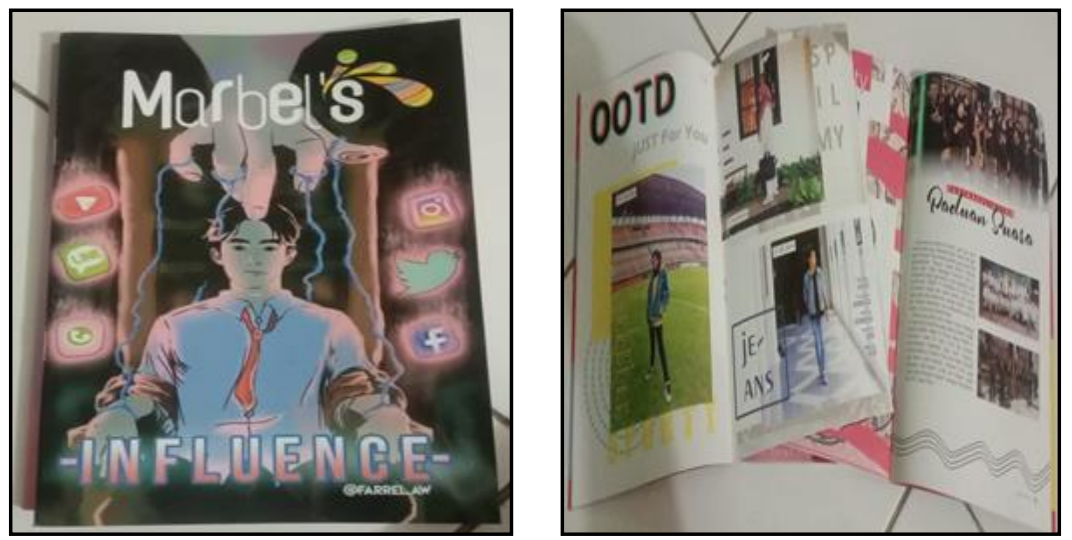

Foto 5: "MARBELS” Majalah Sekolah 


\section{SIMPULAN}

Berbagai laporan dari lembaga kompeten menunjukkan bahwa tingkat literasi masyarakat Indonesia masih sangat memprihatinkan. Berkaitan dengan hal tersebut, kepala sekolah, sebagai seorang top manajer di sekolah yang dipimpinnya, memiliki tugas penting, tidak hanya berkaitan dengan peningkatan kualitas pembelajaran, tetapi juga kualitas pendidikan. Untuk tujuan tersebut, perlu adanya inovasi.

Permasalahan yang dihadapi Sekolah dalam kaitannya dengan budaya literasi (membaca dan menulis) masih belum sesuai dengan yang diharapkan. Budaya literasi yang belum tumbuh tersebut dipengaruhi oleh beberapa faktor, yakni peserta didik, guru, dan sekolah.

Pelaksanaan program gerakan literasi sekolah dilakukan melalui beberapa tahap kegiatan, yakni tahap perencanaan, pelaksanaan, dan evaluasi.

Pada tahap perencanaan, kegiatan yang dilakukan adalah penyusunan tim pelaksana program, pengoordinasian awal untuk merencanakan program, penyusunan program dan rencana anggaran, dan pemberian sosialisasi.

Pada tahap pelaksanaan program ada beberapa kegiatan yang dilakukan, yakni kunjungan ke perpustakaan, membaca buku nonpelajaran sebelum kegiatan pembelajaran dimulai, membuat mading di setiap kelas, membuat pohon literasi di setiap kelas, posterisasi sekolah, membuat dinding motivasi di setiap kelas, membuat sudut baca, dan mengadakan lomba karya literasi antarkelas.

Pada tahap evaluasi dilakukan penilaian keterlaksanaan program sejak awal sampai dengan akhir tahun pelajaran. Pelaksanaan evaluasi dilakukan dengan mengumpulkan seluruh anggota tim GLS. Pada pelaksanaan evaluasi tersebut, masing-masing koordinator bidang memberikan gambaran pelaksanaan program, baik kelebihan maupun kendala yang dihadapi saat program diimplementasikan. Hasil evaluasi dijadikan dasar perbaikan pada periode berikutnya.

\section{DAFTAR RUJUKAN}

Beers, dkk (2009). A Principal's Guide to Literacy Instruction. Diakses dari www.bibliotech.us/pdfs/ InfoLit. pdf. Diakses pada 13 Juni 2019.

Clay \& Ferguson. Diakses dari www.bibliotech.us/pdfs/InfoLit.pdf. pada 13 Juni 2019.

Dewayani, S. \& Retnaningdyah, P. (2017). Suara dari Marjin: Literasi sebagai Praktik Sosial. Bandung: Remaja Rosdakarya.

Direktorat Jenderal Pendidikan Dasar dan Menengah, Kementrian Pendidikan dan Kebudayaan Republik Indonesia. (2016). Panduan Gerakan Literasi di Sekolah Menengah Atas, tersedia dari: http:// dikdas. kemdikbud.go.id/. pada 10 Juni 2019.

https://kompas.id/baca/foto/2019/02/23/minat-baca-warga-indonesia-rendah.

https://www.kominfo.go.id/ Diunduh pada 13 Juni 2019.

Laksono, Kisyani, dkk. (2016). Manual Pendukung Gerakan Literasi Sekolah: Untuk Jenjang Sekolah Menengah Pertama. Jakarta: Direktorat Pembinaan SMP.

Mulyasa. (2007). Menjadi Kepala Sekolah yang Profesional. Bandung: PT Remaja Rosdakarya.

Musfah, J. (2010). Kepemimpinan Kepala Sekolah. Jakarta: UIN Syarif Hidayatullah. 
Peraturan Menteri Pendidikan dan Kebudayaan (Permendikbud) Nomor 23 Tahun 2015. diunduh pada 13 Juni 2019.

PISA 2012 Result in Focus. (2014). Diakses dari https:// www.oecd.org/pisa/ keyfindings/pisa-2012results-overview.pdf, pada 13 Juni 2019.

PISA 2015 Result in Focus: What 15 Year Old Know and What They Can do With What They Know. (2016). Diakses dari https: //www.oecd.org /pisa/pisa-2015-results-in-focus.pdf, pada 13 Juni 2019.

Rencana Pembangunan Jangka Menengah Nasional (RPJMN) 2015-2019. Diunduh pada 12 Juni 2019.

Wiedarti, P. dkk. (2016). Desain Induk Gerakan Literasi Sekolah. Direktorat Jenderal Pendidikan Dasar dan Menengah Kemdikbud.

www.bibliotech.us/pdf/infolit.pdf. Diakses pada 23 Maret 2020. 